\title{
34. BASALT WEATHERING ON THE EAST PACIFIC RISE AND THE GALAPAGOS SPREADING CENTER, DEEP SEA DRILLING PROJECT LEG 54
}

\author{
Susan E. Humphris, ${ }^{1}$ Department of Geology, Imperial College of Science and Technology, Prince Consort Road, \\ London SW7 2BP, England \\ William G. Melson, Department of Mineral Sciences, Smithsonian Institution, Washington, D.C. \\ and \\ Robert N. Thompson, Department of Geology, Imperial College of Science and Technology, \\ Prince Consort Road, London SW7 2BP, England
}

\begin{abstract}
The mineralogical and geochemical changes during the early stages of weathering of two suites of basalts from the East Pacific Rise and from the hydrothermal mound area near the Galapagos Spreading Center have been investigated. Three compositional groups of smectites were observed: an $\mathrm{FeO}^{*}$ and $\mathrm{K}_{2} \mathrm{O}$-rich variety, an $\mathrm{MgO}$-rich type most closely resembling saponite, and a group with compositions intermediate between them. Other secondary minerals included carbonates, particularly an Mn-rich variety, hydrated iron oxides, and minor pyrite.

Geochemical comparison of the weathered rims and fresh interiors of individual samples indicated an increase in the $\mathrm{K}_{2} \mathrm{O}$ and $\mathrm{Rb}$ contents and $\mathrm{Fe}_{2} \mathrm{O}_{3} / \mathrm{FeO}$ ratio, and a slight decrease in the $\mathrm{CaO}$ content in the weathered rims, even though their $\mathrm{H}_{2} \mathrm{O}^{+}$contents were often less than 1 per cent.

The similar weathering processes that appear to have affected both suites of rocks, and the absence of any secondary minerals that are formed exclusively under hydrothermal conditions in the samples from the hydrothermal mounds area, would indicate that either circulation may be confined to a few narrow fractures - thereby restricting high-temperature alteration to the margins of basalts adjacent to the fractures - or that most of the hydrothermal minerals are formed at greater depths in the basaltic column.
\end{abstract}

\section{INTRODUCTION}

Interactions between sea water and rock at various temperatures in the oceanic crust have recently been studied in attempts to assess their importance for elemental fluxes into and out of the oceans (e.g., Thompson, 1973; Humphris and Thompson, 1978; Donnelly et al., in press; and Humphris et al., in press). Most of these studies have been confined to rocks dredged or drilled in the Atlantic Ocean. Although our knowledge of mineralogical and chemical variations during reactions with sea water is improving, our understanding of alteration processes as a function of age, basalt chemistry, and tectonic setting is very limited.

The purpose of this paper is to investigate the early stages of weathering (i.e., less than 3 m.y.B.P.) in two suites of samples recovered during Leg 54 which originated at different spreading centers in the Pacific Ocean

\footnotetext{
${ }^{1}$ Present address: Sea Education Association, Woods Hole, Massachusetts.
}

- the East Pacific Rise and the Galapagos Spreading Center. The basalts erupted at these two spreading centers are chemically distinct from each other (Fodor et al., Srivistava et al., and Humphris et al.; all this volume) and from Mid-Atlantic Ridge basalts.

In addition, the samples studied also represent several different tectonic settings. Three major structural features were drilled in the region of the East Pacific Rise near $9^{\circ} \mathrm{N}$ (Figure 1): the East Pacific Rise flank fabric (Sites 420, 421, 423, and 429), the east-west trending OCP Ridge (Sites 422 and 428 ), and the Siqueiros fracture zone (Site 427). The Galapagos Spreading Center drilling included a north-south transect across a hydrothermal field $22 \mathrm{~km}$ south of the spreading center, which had previously been surveyed by Klitgord and Mudie (1974) and Lonsdale (1977) - Site 424. The basalts were overlain by hydrothermal sediments and so could have been subjected to a thermal regime different from that of the other sites. Site 425 was located $62 \mathrm{~km}$ north of the Galapagos Spreading Center in an area characterized by high heat flow. 


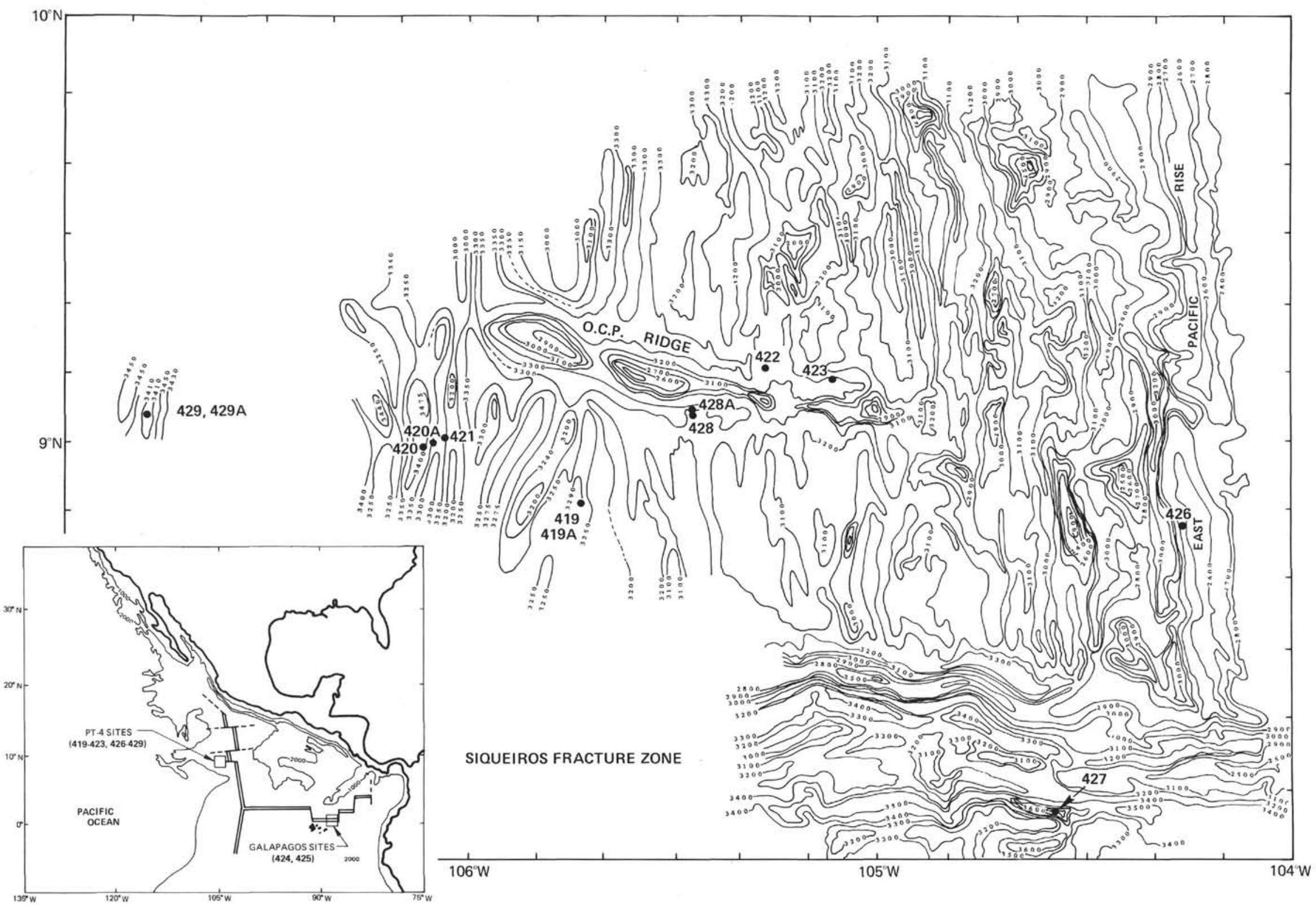

Figure 1. The location of sites drilled on Deep Sea Drilling Project Leg 64 near the East Pacific Rise and Galapagos Spreading Center (inset). 


\section{ALTERATION MINERALOGY}

Weathering processes affecting all the rocks recovered on Leg 54 have generally been confined to the infilling of veins and vesicles by clay minerals and carbonates, and to the formation of surface coatings on samples from both the East Pacific Rise and the Galapagos Spreading Center. In addition, many of the samples exhibit a well-defined rim, which is usually 1 to $3 \mathrm{~cm}$ wide and pale grey in color. Minor alteration of phenocrysts and groundmass phases and infilling of vesicles appear to have been responsible for this zonation. These weathered rims indicate that many of the rock surfaces have been exposed to sea water, suggesting that the oceanic crust in this area consists of highly jointed flows or small pillows.

\section{Surface Coatings}

Clay minerals constitute the most abundant surface coating and are found lining depressions in rock surfaces and infilling vugs in samples from the East Pacific Rise and the Galapagos Spreading Center. They are usually pale green or blue in color and form coatings of up to $1 \mathrm{~mm}$ thick. Scanning electron microphotographs indicate that these surface coatings are composed of a complex network of ramose (branching, twig-like) structures which project from the rock surface (Plate 1, Figure 1). Details of these ramose structures are shown in Plate 1 (Figure 2), which illustrates the radiating and interwoven nature of the clay mineral plates. Several samples of this surface coating were removed for X-ray diffraction study. Glycerol saturation of oriented samples results in expansion of the basal spacing from $14 \AA$ to $17.5 \AA$, which subsequently collapsed on heating. A 060 peak of $1.533 \AA$ was observed, indicating that this smectite is trioctahedral.

The smectites are often associated with later-stage carbonates. Large vugs up to $1.2 \mathrm{~cm}$ in diameter (in Section 427-9-2, Piece 4) show two generations of calcite, and calcite veins are common in many samples. X-ray diffraction and qualitative analysis using an energy dispersive X-ray spectrometer (EDAX) were used to identify a manganese-rich calcite. The latter occurred as a cream, globular surface deposit found on samples from Hole 427 in the Siqueiros fracture zone (Plate 2, Figure 1). Scanning electron microphotographs (Plate 2, Figures 2 and 3 ) indicate that these globules are composed of parallel columns of stacked platelets. X-ray diffraction data are given in Table 1 and, although the major calcite peaks are clearly distinguishable, the whole pattern is slightly displaced owing to the manganese substitution. A manganese-rich carbonate has been observed replacing plagioclase phenocrysts in highly weathered basalts from the Bermuda Rise (Humphris et al., in press), but its existence as a surface deposit has thus far not been reported from ocean floor basalts.

Hydrated iron oxides cover the surface of many samples, and these are often associated with glassy margins of pillows or flows that are partially weathered. Pyrite occurs in small surface depressions (e.g., Section
TABLE 1

XRD Data for Manganese-Rich Calcite ${ }^{a}$

\begin{tabular}{|c|c|c|}
\hline hkl & d Spacing $(\AA)$ & Intensity \\
\hline 104 & 2.958 & Very strong \\
\hline 018 & 1.868 & Strong \\
\hline 116 & 1.812 & Medium (broad) \\
\hline 113 & 2.224 & Medium \\
\hline 202 & 2.035 & Weak \\
\hline 110 & 2.462 & Very weak \\
\hline
\end{tabular}

427-11-1, Piece 3) or in vesicles (e.g., Section 425-9-3, Piece 5), but is extremely rare.

\section{Basalt Alteration}

It should be emphasized that all of the samples show only the early stages of weathering - i.e., infilling of some vesicles and veins, very occasional phenocryst alteration, and minor patchy replacement of the groundmass. Generally, less than 2 per cent of the rock has been affected, and this is confined to the outer weathered rim. Basalts from Site 425 near the Galapagos Spreading Center appear to be the most altered, with up to 4 volume per cent being affected. Samples with doleritic textures (i.e., from the OCP Ridge Sites 422 and 428 , and from some sections of the Siqueiros fracture zone, Site 427) appear to have been less affected by weathering (less than 1 vol. \%) than the quenched basalts. Alteration of phenocrysts is observed in only a few samples, and olivine appears to be the most affected phase. It is pseudomorphed by fine-grained aggregates of green smectite, which are often associated with hydrated iron oxides (eg., Section 427-11-1, Piece 4), or occasionally with cubes of pyrite (e.g., Section 428A$1-1$, Piece 13). This smectite varies in color from bright green to yellow-green, and exhibits blue-green interference colors. In Hole 424C, drilled on the Galapagos Spreading Center, the olivine is replaced by a low birefringent, orange-brown smectite. In Section 429A-1-1, Piece 5 , some plagioclase phenocrysts are replaced by white to pale green clay minerals with an infilling of calcite, but plagioclase alteration did not occur at any other site.

The groundmass of many basalts contains small patches of clay minerals. Bright green smectites are the most abundant, but light brown and orange-brown clay minerals do occur. The orange-brown smectites also form narrow rims outlining crystals. A relatively common feature is color zonation of the larger patches from green rims to light brown to red in the centers. The interiors are opaque and dark red, and resemble hydrated iron oxides. However, attempts to analyze these by microprobe indicate that they probably consist of intimate mixtures of iron oxides and clay minerals. Calcite occurs as a minor secondary mineral replacing the groundmass, particularly in samples from Sites $\mathbf{4 2 8}$ and 427 , where it may or may not be associated with smectites. 
Vesicles commonly contain secondary minerals in the weathered rims of the basalts, but are usually empty in the interiors. They are filled with: (1) bright green smectites; (2) light brown smectites; (3) a fine-scale zonation of green rims and brown interiors; (4) bright orangebrown smectites, similar in appearance to those rimming crystals; (5) dark red mixtures of hydrated iron oxides and smectites; (6) green or brown smectite lining with a core of chalcedony (Site 429A); and (7) in Section 425-7-1, Piece 6, a green rim infilled with white radiating needles of a zeolite. Different vesicle fillings occur within a single sample. However, the proportion of orange-brown and light brown smectites to green smectites appears to increase toward the margin of the samples. This may be related to the oxidation state of the iron in the smectite and not to a compositional change.

Representative microprobe analyses of the clay minerals from both the East Pacific Rise and the Galapagos Spreading Center are reported in Table 2; each result is the average of at least five analyses. For all sites, the major type of smectite is enriched in $\mathrm{FeO}^{*}$ (expressing total $\mathrm{Fe}$ ) and $\mathrm{K}_{2} \mathrm{O}$. This occurs as pseudomorphs after olivine, replacing the groundmass and infilling vesicles. Its color varies from bright green to light brown and its composition is generally characterized by low $\mathrm{Al}_{2} \mathrm{O}_{3}, 26$ to 30 per cent $\mathrm{FeO}^{*}, 1$ to 5 per cent $\mathrm{MgO}$, and up to 6 per cent $\mathrm{K}_{2} \mathrm{O}$ content. The bright orange-brown smectite that rims crystals and replaces the groundmass contains a higher concentration of iron - up to 36 per cent in Section 429A-1-1, Piece 5. Two other distinctly different compositions can be observed. The white to pale green smectite replacing the plagioclase phenocrysts appears to resemble saponite most closely in composition (Table 2, analyses 20 and 21), and contains 22 to 24 per cent $\mathrm{MgO}$ and 5 to 6 per cent $\mathrm{FeO}^{*}$. This mineral was identified only in Hole 429A, and only in this mineralogical setting.

The other compositional variation observed is intermediate between the $\mathrm{Fe}$-rich and $\mathrm{Mg}$-rich types, and this smectite occurs as a bright green vesicle filling in Sample Section 428A-3-1, Piece 11 (Table 2, Analysis 8). It contains 22 per cent $\mathrm{FeO}^{*}$ and 14 per cent $\mathrm{MgO}$, and may represent either a fine-grained mixture of two smectites or a mixed-layer clay mineral.

All the microprobe data from this study are plotted on a triangular $\mathrm{SiO}_{2}-\mathrm{FeO}^{*}-\mathrm{MgO}$ diagram, with the weight percentages of $\mathrm{K}_{2} \mathrm{O}$ plotted on a vertical axis (Figure 2). These are compared with clay mineral compositions from 110-m.y.-old basalts from the Bermuda Rise (Humphris et al., in press) and from 40-m.y.-old basalts from the Peru Trench (Scheidegger and Stakes, 1977). This comparison shows that $\mathrm{Fe}$ - and $\mathrm{K}$-enriched smectites are the most abundant type of clay mineral found in the basalts studied from both the Atlantic and Pacific Oceans. However, the clay minerals found in the East Pacific Rise and Galapagos Spreading Center basalts are generally more $\mathrm{Fe}$-rich than those from the Bermuda Rise. This could be related either to the higher FeO* content of the more evolved Pacific basalts, which may influence the composition of the fluid from which the clay minerals formed, or to later cation exchange of the clay minerals from the Atlantic.

The "saponite-type" smectites replacing phenocrysts in Hole 429A are some of the most Mg-rich clay minerals analyzed from ocean floor basalts, and their formation is probably the result of rigidly localized physical and chemical conditions. A separate compositional group intermediate between the $\mathrm{Mg}$-rich and Fe-rich end members is comprised of smectites from the Peru Trench and from the Bermuda Rise basalts. The absence of these intermediate smectites in the young East Pacific Rise and the Galapagos Spreading Center basalts suggests they are formed at a later stage of alteration, either by precipitation from a fluid of different composition or by cation exchange in pre-existing clay minerals.

\section{GEOCHEMISTRY}

Although all of the basalts recovered during Leg 54 are less than $5 \mathrm{~m}$.y. old and appear relatively fresh, the early stages of alteration and formation of clay minerals should be reflected in changes in the bulk chemistry. Thirteen samples, for which the weathered rims previously discussed could be separated from the fresh cores, were selected for X-ray fluorescence (XRF) analyses. This approach permits direct comparison of the composition of the weathered rims with that of their fresh precursors; hence, it eliminates errors involved in assuming the composition of the fresh rock. Precision and accuracy of the analytical methods used are discussed in Humphris et al. (this volume). Details of the lithology, texture, and petrology of the selected samples are presented in Table 3.

Major- and selected trace-element analyses are presented in Table 4. Although most of the $\mathrm{H}_{2} \mathrm{O}^{+}$contents are less than 1 per cent, with only three rims showing higher concentrations, it is clear that some of the oxides and elements, particularly $\mathrm{Fe}_{2} \mathrm{O}_{3}, \mathrm{~K}_{2} \mathrm{O}$, and $\mathrm{Rb}$, show significant alteration effects.

To make comparisons of the fresh interiors to the altered rims more meaningful, it is necessary to normalize the data. This can be accomplished by taking the ratio of each oxide to one that is relatively unaffected by weathering, such as alumina or titania. If the concentrations of both these oxides are unchanged by weathering, then their ratio in the fresh sample interior should be equal to that in the altered rim. This is illustrated in Figure 3, which demonstrates that the ratio of $\mathrm{Al}_{2} \mathrm{O}_{3}$ / $\mathrm{TiO}_{2}$ remains virtually unchanged during alteration of these samples. Thus, either $\mathrm{Al}_{2} \mathrm{O}_{3}$ or $\mathrm{TiO}_{2}$ could be used for normalization; we will, however, use $\mathrm{Al}_{2} \mathrm{O}_{3}$ in this discussion since it is present in higher concentrations.

The most significant variations in chemical composition are observed in the iron concentrations. All the samples indicate that there is an increase in the total iron concentration during weathering (Figure 4), although this increase is not as pronounced in the more crystalline samples from the OCP Ridge and the Galapagos Spreading Center. Mineralogically, this is exhibited by the high iron content of the smectites replacing the groundmass and forming pseudomorphs after olivine. Oxidation has also been an important weathering pro- 
cess - the $\mathrm{Fe}_{2} \mathrm{O}_{3}$ content of the rims is greater than that of the cores (Figure 5) - and the ferrous component shows only minor variations in concentrations (Figure 6). This would indicate that important changes in the concentrations of oxides occur during the earlier stages of weathering, which would not be evident from a bulk chemical analysis of a rock and its $\mathrm{H}_{2} \mathrm{O}+$ content. Such variations, particularly in the iron concentration, may affect conclusions drawn from norm calculations and from magma fractionation modeling.

The slightly lower $\mathrm{CaO}$ contents of most of the altered rims in comparison with the fresh cores (Figure 7) are in agreement with the decrease in calcium generally observed in more highly weathered basalts (e.g., Hart, 1970; and Thompson, 1973). Strontium also shows a decrease in concentrations in the weathered rims. The slightly higher $\mathrm{CaO}$ contents of the rim shown by two of the samples are probably a consequence of either minor replacement of the groundmass by calcite or of the incorporation of calcite veinlets into the sample.

The concentrations of $\mathrm{MgO}$ show some scatter about the line and, in general, appear to show only minor variations (Figure 8). However, higher $\mathrm{MgO}$ contents in the rims are indicated for a few samples. Since there is no

TABLE 2

Representative Microprobe Analyses of Clay Minerals from Basalts of the East Pacific Rise and the Galapagos Spreading Center

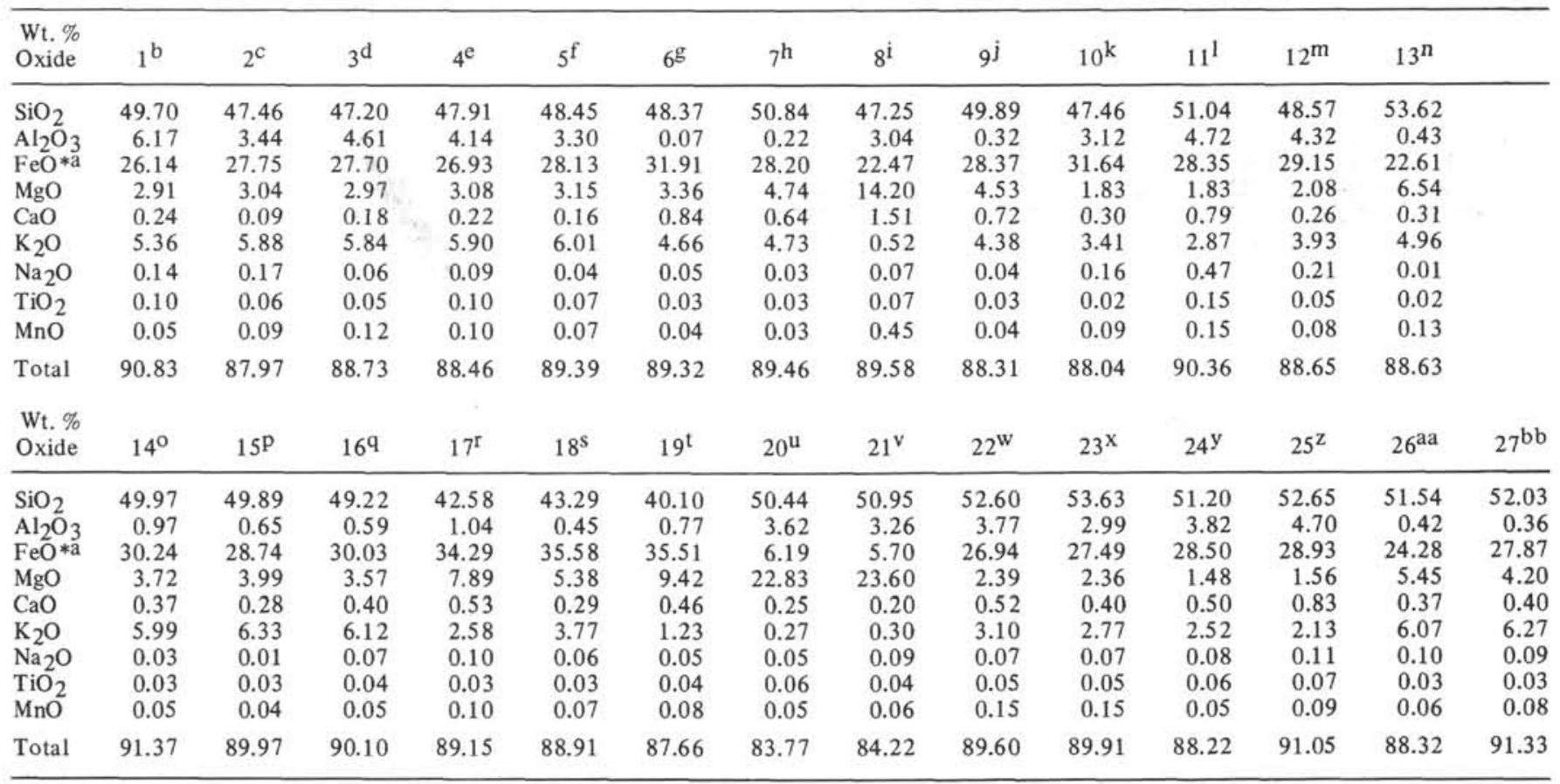

a $\mathrm{FeO}^{*}=$ total iron expressed as $\mathrm{FeO}$.

${ }^{b}$ Green clay mineral associated with hydrated iron oxide pseudomorphing olivine phenocryst: Section 427-11-1, Piece 4;

cGreen clay mineral replacing groundmass: Section 427-11-1, Piece 4;

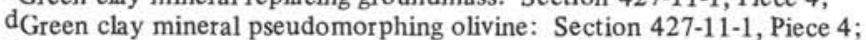

eGreen clay mineral after olivine: Section 427-11-1, Piece 4;

fYellow-green vein filling: Section 427-11-1, Piece 4;

gGreen clay mineral replacing groundmass: Section 428A-3-1, Piece 11;

h Green clay mineral replacing groundmass: Section 428A-3-1, Piece 11;

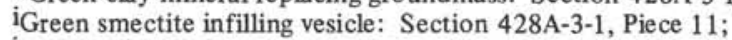

jGreen smectite replacing groundmass: Section 428A-3-1, Piece 11;

KOrange-brown smectite replacing groundmass: Section 424C-2-1, Piece 4;

lOrange-brown smectite pseudomorphing phenocryst: Section 424C-2-1, Piece 4;

mOrange-brown clay mineral replacing groundmass: Section 424C-2-1, Piece 4;

nInterior of vesicle: Section $429 \mathrm{~A}-1-1$, Piece 5;

outer rim of same vesicle: Section 429A-1-1, Piece 5;

PGreen smectite infilling small vesicle: Section 429A-1-1, Piece 5;

qGreen vesicle filling: Section 429A-1-1, Piece 5;

rOrange-brown clay mineral replacing groundmass: Section 429A-1-1, Piece 5;

SBrown clay mineral replacing groundmass: Section 429A-1-1, Piece 5;

tBrown clay mineral replacing groundmass: Section 429A-1-1, Piece 5;

uWhite-pale green smectite replacing plagioclase phenocryst and associated with calcite: Section 429A-1-1, Piece 5;

vale green smectite replacing plagioclase phenocryst: Section 429A-1-1, Piece 5;

$w_{G r e e n}$ smectite infilling vesicle: Section 421-3-1, Piece 20;

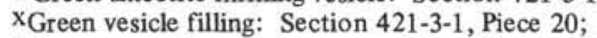

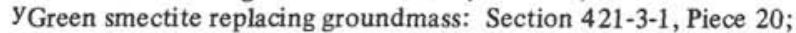

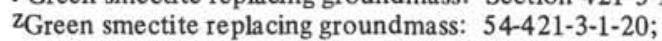

aa Green rim of vesicle infilled with zeolite: Section 425-7-1, Piece 6; and

bbGreen vesicle filling: Section 425-7-1, Piece 6. 


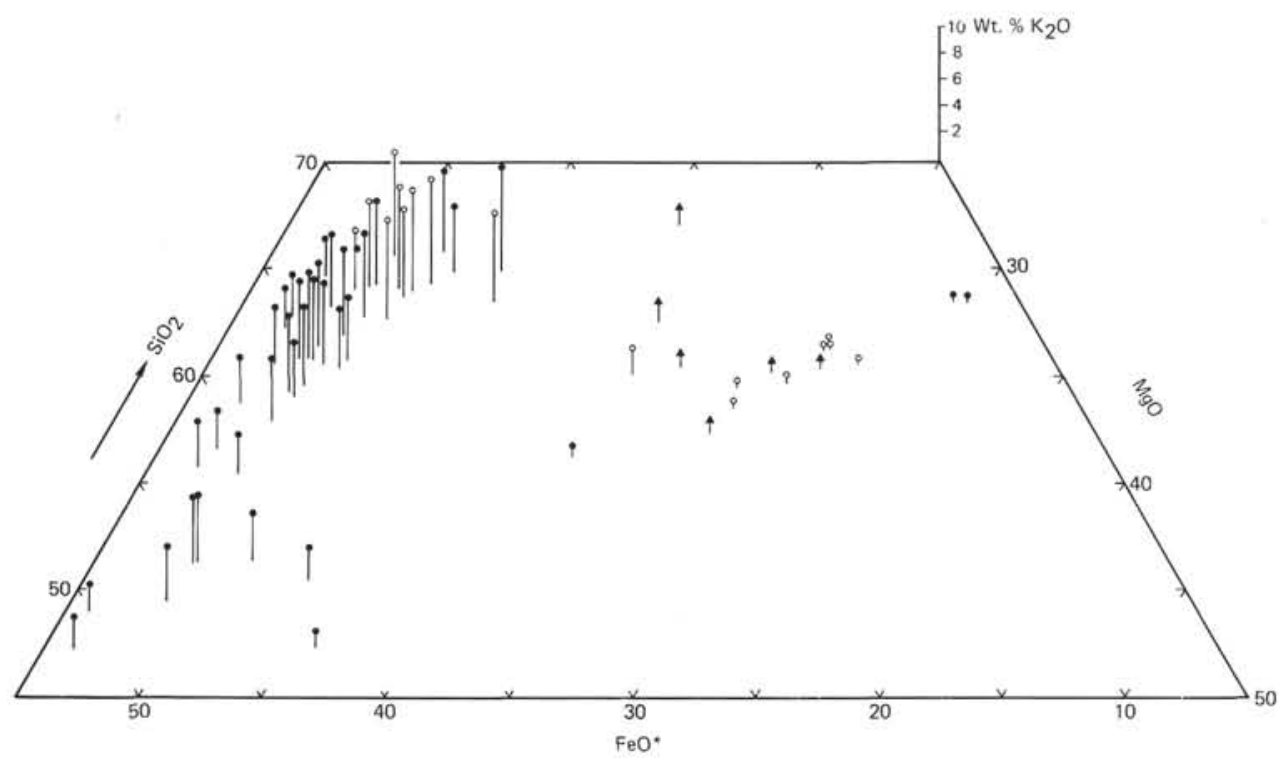

Figure 2. $\mathrm{SiO}_{2}-\mathrm{FeO} *-\mathrm{MgO}$ triangular diagram, with wt. $\% \mathrm{~K}_{2} \mathrm{O}$ plotted on a vertical axis, presenting the composition of secondary clay minerals found in some weathered oceanic basalts ( $\mathrm{FeO}$ expresses total $\mathrm{Fe}$ ). = clay minerals from the East Pacific Rise and Galapagos Spreading Center (this study); = clay minerals from the Bermuda Rise, Atlantic Ocean (Humphris et al., in press); = clay minerals from the Peru Trench (Scheidegger and Stakes, 1977).

evidence for uptake of significant quantities of $\mathrm{MgO}$ in the compositions of the smectites from these samples, these variations in the $\mathrm{MgO}$ content may be a reflection of inhomogeneous distribution of primary phases within the thin flows or pillows.

Previous studies have shown that $\mathrm{K}_{2} \mathrm{O}$ is generally taken up during basalt weathering, and it has been suggested that this process may be an important sink for potassium in the oceans (e.g., Melson and Thompson, 1973; Donnelly et al., in press; and Humphris et al., in press). The weathered rims of the young basalts from the East Pacific Rise and the Galapagos Spreading Center also show overall increases in the $\mathrm{K}_{2} \mathrm{O}$ content of the rocks (Figure 9) with concomitant increases in the $\mathrm{Rb}$ concentrations. This is the result of formation of the $\mathrm{K}$ - and $\mathrm{Fe}$-enriched smectites in these samples. The $\mathrm{K}_{2} \mathrm{O}$ concentrations observed in the fresh interiors of the more crystalline samples are lower than those found in the finer grained basalt. This may indicate that weathering has affected the interiors of the fine-grained basalts as well as the rims, whereas the crystalline cores have retained a $\mathrm{K}_{2} \mathrm{O}$ content closer to their original levels. Ocean floor basalts clearly provide a sink for $\mathrm{K}$ and begin to remove this element from sea water during the very early stages of weathering. These results suggest that the bulk rock $\mathrm{K}_{2} \mathrm{O}$ content is affected by the initial weathering processes which consist mostly of clay mineral formation in vesicles, and which may affect only 1 per cent of the rock. Many of the basalts dredged or drilled from the ocean floor contain smectite-filled vesicles, suggesting that the early stages of weathering are a common feature. These observations would therefore support the contention that weathering can be an important sink for potassium in the oceans.
Variations in $\mathrm{Na}_{2} \mathrm{O}$ concentrations are small and show no consistent trends, suggesting that the early stages of weathering do not alter the $\mathrm{Na}_{2} \mathrm{O}$ contents of the basalts (Figure 10). This is in contrast with studies of more highly weathered basalts, in which uptake of $\mathrm{Na}_{2} \mathrm{O}$ has been observed (Hart, 1970).

\section{DISCUSSION AND CONCLUSIONS}

The major type of alteration in the basalts from Leg 54 is the formation of smectites. There is no evidence for their absolute temperature of formation, but the lack of zeolites and chlorite suggests that alteration occurred predominantly at low temperatures. Smectite formation, the presence of calcite, and the increase in the $\mathrm{Fe}_{2} \mathrm{O}_{3} / \mathrm{FeO}$ ratio in the weathered rims indicate that alkaline, oxidizing conditions (which could be provided by sea water) prevailed during alteration of these rocks. The occurrence of chemically similar smectites from the East Pacific Rise, the Galapagos Spreading Center, and the Bermuda Rise suggests that $\mathrm{K}$ - and Fe-enriched smectites can be formed regardless of variations in basalt chemistry. If these smectites are typical of the early stages of low-temperature weathering of basalts, this would indicate that the chemical variations in the composition of the basalts are initially unimportant. This may be explained by the observation that olivine and the interstitial material are usually the first to be altered. It is not until other phases, such as plagioclase and pyroxene, are altered, that the effects of variations in basalt chemistry are detected. For instance, the smectites from these young basalts contain very little alumina. However, it is likely that as weathering advances, and plagioclase is altered, the smectites formed will be more aluminous. 
TABLE 3

Samples Subjected to Bulk Chemical Analyses of their Fresh Interiors and Weathered Rims

\begin{tabular}{|c|c|c|c|c|c|}
\hline \multirow[b]{2}{*}{ Specimen } & \multirow[b]{2}{*}{ Location } & \multirow[b]{2}{*}{ Lithology } & \multirow[b]{2}{*}{ Texture } & \multicolumn{2}{|c|}{ Petrographic Notes } \\
\hline & & & & Fresh Interior & Weathered Rim \\
\hline $\begin{array}{l}\text { Section 420-14-1, } \\
\text { Piece } 3\end{array}$ & EPR flank fabric & $\begin{array}{l}\text { Interior of highly } \\
\text { jointed flow }\end{array}$ & Aphyric; fine-grained & $\begin{array}{l}\text { Plagioclase, clinopyrox- } \\
\text { ene, minor olivine, glass }\end{array}$ & $\begin{array}{l}\text { Green smectite patchily } \\
\text { replacing groundmass. } \\
\text { Zoned vesicles. } \\
\text { Weathering }-2 \%\end{array}$ \\
\hline $\begin{array}{l}\text { Section 421-3-1, } \\
\text { Piece } 14\end{array}$ & EPR flank fabric & $\begin{array}{l}\text { Fragment of highly } \\
\text { jointed thin flow }\end{array}$ & $\begin{array}{l}\text { Fine-grained; iso- } \\
\text { lated pcs with glo- } \\
\text { merophyric } \\
\text { clusters }\end{array}$ & $\begin{array}{l}\text { Plagioclase and olivine } \\
\text { phyric }\end{array}$ & $\begin{array}{l}\text { Green and brown smec- } \\
\text { tites replacing ground- } \\
\text { mass and filling vesicles. } \\
\text { Weathering }<1 \%\end{array}$ \\
\hline $\begin{array}{l}\text { Section 421-3-1, } \\
\text { Piece } 18\end{array}$ & EPR flank fabric & $\begin{array}{l}\text { Fragment of highly } \\
\text { jointed thin flow }\end{array}$ & $\begin{array}{l}\text { Fine-grained; } \\
\text { glomerophyric }\end{array}$ & $\begin{array}{l}\text { Plagioclase and olivine } \\
\text { glomerocrysts. } \\
\text { Empty vesicles }\end{array}$ & $\begin{array}{l}\text { Patchy replacement of } \\
\text { groundmass. Filled } \\
\text { vesicles. } \\
\text { Weathering }<1 \%\end{array}$ \\
\hline $\begin{array}{l}\text { Section 421-4-1, } \\
\text { Piece } 5\end{array}$ & EPR flank fabric & $\begin{array}{l}\text { Fragments of jointed } \\
\text { flow or pillow }\end{array}$ & Glomerophyric & $\begin{array}{l}\text { Plagioclase, olivine and } \\
\text { clinopyroxene. Some } \\
\text { vesicles filled }\end{array}$ & $\begin{array}{l}\text { Patchy groundmass } \\
\text { alteration. Vesicles } \\
\text { filled with green smec- } \\
\text { tites or zoned. } \\
\text { Weathering - } 1 \%\end{array}$ \\
\hline $\begin{array}{l}\text { Sample 423-5- } \\
\text { CC-1 }\end{array}$ & EPR flank fabric & $\begin{array}{l}\text { Edge of thin, } \\
\text { basaltic flow }\end{array}$ & $\begin{array}{l}\text { Fine-grained; } \\
\text { variolitic }\end{array}$ & $\begin{array}{l}\text { Plagioclase, clinopyrox- } \\
\text { ene; dominantly glassy } \\
\text { matrix }\end{array}$ & $\begin{array}{l}\text { Green and orange- } \\
\text { brown smectites fill } \\
\text { vesicles and replace } \\
\text { groundmass. Sulfides. } \\
\text { Weathering } \sim 2 \%\end{array}$ \\
\hline $\begin{array}{l}\text { Section 425-7-1, } \\
\text { Piece } 6\end{array}$ & $\begin{array}{l}62 \mathrm{~km} \text { north of } \\
\text { Galapagos Spreading } \\
\text { Center }\end{array}$ & $\begin{array}{l}\text { Interior of cooling } \\
\text { unit }\end{array}$ & Intersertal & $\begin{array}{l}\text { Plagioclase, clinopyrox- } \\
\text { ene, with minor glass. } \\
\text { Vesicles empty }\end{array}$ & $\begin{array}{l}\text { Green and brown smec- } \\
\text { tites. Sulfide minerali- } \\
\text { zation. } \\
\text { Weathering }-1 \%\end{array}$ \\
\hline $\begin{array}{l}\text { Section 425-9-3, } \\
\text { Piece } 5\end{array}$ & $\begin{array}{l}62 \mathrm{~km} \text { north of } \\
\text { Galapagos Rift }\end{array}$ & $\begin{array}{l}\text { Interior of cooling } \\
\text { unit }\end{array}$ & $\begin{array}{l}\text { Holocrystalline, } \\
\text { equigranular }\end{array}$ & $\begin{array}{l}\text { Plagioclase, clinopyrox- } \\
\text { ene and opaques }\end{array}$ & $\begin{array}{l}\text { Green clay minerals } \\
\text { replacing groundmass. } \\
\text { Weathering } \sim 1 \%\end{array}$ \\
\hline $\begin{array}{l}\text { Section 428A-2-1, } \\
\text { Piece } 2\end{array}$ & $\begin{array}{l}\text { South side of OCP } \\
\text { Ridge }\end{array}$ & Interior of thin flow & $\begin{array}{l}\text { Cryptocrystalline, } \\
\text { massive }\end{array}$ & $\begin{array}{l}\text { Plagioclase, clinopyrox- } \\
\text { ene and minor olivine }\end{array}$ & $\begin{array}{l}\text { Groundmass patchily } \\
\text { replaced by smectites, } \\
\text { sometimes with sulfide. } \\
\text { Weathering }<1 \%\end{array}$ \\
\hline $\begin{array}{l}\text { Section 428A-6-1, } \\
\text { Piece } 6\end{array}$ & $\begin{array}{l}\text { South side of OCP } \\
\text { Ridge }\end{array}$ & $\begin{array}{l}\text { Interior of slowly } \\
\text { cooled unit }\end{array}$ & Equigranular & $\begin{array}{l}\text { Plagioclase, clinopyrox- } \\
\text { ene and opaques }\end{array}$ & $\begin{array}{l}\text { Patchy groundmass } \\
\text { replacement by brown } \\
\text { smectites. } \\
\text { Weathering } 1 \%\end{array}$ \\
\hline $\begin{array}{l}\text { Section 428A-6-1, } \\
\text { Piece } 14\end{array}$ & $\begin{array}{l}\text { South side of OCP } \\
\text { Ridge }\end{array}$ & $\begin{array}{l}\text { Interior of slowly } \\
\text { cooled unit }\end{array}$ & Equigranular & $\begin{array}{l}\text { Plagioclase, clinopyrox- } \\
\text { ene and opaques }\end{array}$ & $\begin{array}{l}\text { Green-brown smectites } \\
\text { replacing groundmass. } \\
\text { Weathering } \sim 1 \%\end{array}$ \\
\hline $\begin{array}{l}\text { Section 429A-2-1, } \\
\text { Piece } 8\end{array}$ & EPR flank fabric & $\begin{array}{l}\text { Pillow basalt or } \\
\text { highly fractured thin } \\
\text { flow }\end{array}$ & $\begin{array}{l}\text { Fine-grained; vario- } \\
\text { litic to intersertal }\end{array}$ & $\begin{array}{l}\text { Plagioclase phyric with } \\
\text { plagioclase, clinopyrox- } \\
\text { ene and opaques }\end{array}$ & $\begin{array}{l}\text { Green smectites replac- } \\
\text { ing groundmass and } \\
\text { infilling vesicles. } \\
\text { Weathering }<1 \%\end{array}$ \\
\hline $\begin{array}{l}\text { Section 429A-2-1, } \\
\text { Piece } 10\end{array}$ & EPR flank fabric & $\begin{array}{l}\text { Pillow basalt or } \\
\text { highly fractured thin } \\
\text { flow }\end{array}$ & $\begin{array}{l}\text { Fine-grained; vario- } \\
\text { litic to intersertal }\end{array}$ & Plagioclase phyric & $\begin{array}{l}\text { Green smectites replac- } \\
\text { ing groundmass and } \\
\text { infilling vesicles. } \\
\text { Weathering }<1 \%\end{array}$ \\
\hline $\begin{array}{l}\text { Section 429A-2-1, } \\
\text { Piece } 16\end{array}$ & EPR flank fabric & $\begin{array}{l}\text { Pillow basalt or } \\
\text { highly fractured thin } \\
\text { flow }\end{array}$ & $\begin{array}{l}\text { Fine-grained; vario- } \\
\text { litic to intersertal }\end{array}$ & $\begin{array}{l}\text { Plagioclase phyric with } \\
\text { plagioclase, clinopyrox- } \\
\text { ene and glass }\end{array}$ & $\begin{array}{l}\text { Green smectites replac- } \\
\text { ing groundmass and } \\
\text { infilling vesicles. } \\
\text { Weathering } \sim 1 \%\end{array}$ \\
\hline
\end{tabular}

The lack of any secondary minerals formed exclusively under hydrothermal conditions at Site 424 in the hydrothermal mounds area near the Galapagos Spreading Center has important implications for circulation of fluids through the oceanic crust. Although overlain by hydrothermal sediment deposits, the samples recovered show only traces of weathering, resembling those at all other sites. There are two possible explanations for this observation. The first is that even in highly jointed flows such as those that constitute the crust in this region, circulation may be confined to a few narrow fractures, thereby restricting reactions to a thin margin of 
TABLE 4

Core and Rim Chemical Analyses for Individual Samples Recovered During Leg 54

\begin{tabular}{|c|c|c|c|c|c|c|c|c|c|c|c|c|}
\hline \multirow[t]{2}{*}{ Specimen: } & \multicolumn{2}{|c|}{ 423-5-CC, Piece 1} & \multicolumn{2}{|c|}{$428 \mathrm{~A}-2-1$, Piece 2} & \multicolumn{2}{|c|}{ 428A-6-1, Piece 6} & \multicolumn{2}{|c|}{ 428A-6-1, Piece 14} & \multicolumn{2}{|c|}{ 421-3-1, Piece 14} & \multicolumn{2}{|c|}{ 421-3-1, Piece 18} \\
\hline & $\begin{array}{c}\text { Outer } \\
\text { Rim }\end{array}$ & Core & $\begin{array}{c}\text { Outer } \\
\text { Rim }\end{array}$ & Core & $\begin{array}{c}\text { Outer } \\
\text { Rim }\end{array}$ & Core & $\begin{array}{l}\text { Outer } \\
\text { Rim }\end{array}$ & Core & $\begin{array}{c}\text { Outer } \\
\text { Rim }\end{array}$ & Core & $\begin{array}{l}\text { Outer } \\
\text { Rim }\end{array}$ & Core \\
\hline $\mathrm{SiO}_{2}{ }^{\mathrm{a}}$ & 50.81 & 51.18 & 50.80 & 51.56 & 49.74 & 50.63 & 50.70 & 50.52 & 50.41 & 51.55 & 49.88 & 51.02 \\
\hline $\mathrm{Al}_{2} \mathrm{O}_{3}$ & 13.99 & 14.43 & 14.65 & 15.71 & 15.07 & 15.47 & 14.99 & 15.23 & 14.00 & 14.63 & 13.83 & 14.54 \\
\hline $\mathrm{Fe}_{2} \mathrm{O}_{3}$ & 4.82 & 2.07 & 5.63 & 3.15 & 4.17 & 2.61 & 4.99 & 3.32 & 5.38 & 3.42 & 5.36 & 3.83 \\
\hline $\mathrm{FeO}$ & 7.18 & 8.01 & 5.41 & 5.27 & 5.66 & 6.53 & 5.57 & 6.06 & 6.67 & 6.38 & 6.78 & 6.42 \\
\hline $\mathrm{MgO}$ & 6.72 & 6.84 & 6.99 & 6.85 & 7.73 & 7.67 & 7.24 & 7.38 & 6.46 & 6.64 & 6.38 & 6.54 \\
\hline $\mathrm{CaO}$ & 10.52 & 11.05 & 11.51 & 12.38 & 11.70 & 12.22 & 11.96 & 12.51 & 10.73 & 11.58 & 10.73 & 11.40 \\
\hline $\mathrm{Na}_{2} \mathrm{O}$ & 2.94 & 3.09 & 2.86 & 3.30 & 2.88 & 2.87 & 2.95 & 2.94 & 2.82 & 3.01 & 2.89 & 3.00 \\
\hline $\mathrm{K}_{2} \mathrm{O}$ & 0.48 & 0.31 & 0.50 & 0.22 & 0.27 & 0.15 & 0.43 & 0.16 & 0.52 & 0.35 & 0.57 & 0.34 \\
\hline $\mathrm{TiO}_{2}$ & 2.05 & 2.14 & 1.51 & 1.58 & 1.38 & 1.45 & 1.47 & 1.48 & 2.06 & 2.24 & 2.12 & 2.25 \\
\hline $\mathrm{P}_{2} \mathrm{O}_{5}$ & 0.23 & 0.22 & 0.16 & 0.16 & 0.16 & 0.14 & 0.15 & 0.15 & 0.21 & 0.22 & 0.19 & 0.23 \\
\hline $\mathrm{MnO}$ & 0.20 & 0.21 & 0.16 & 0.16 & 0.16 & 0.16 & 0.17 & 0.16 & 0.20 & 0.21 & 0.20 & 0.20 \\
\hline $\mathrm{H}_{2} \mathrm{O}^{+}$ & 0.82 & 0.59 & 0.65 & 0.30 & 0.61 & 0.67 & 0.87 & 0.55 & 0.91 & 0.67 & 1.02 & 0.41 \\
\hline $\mathrm{CO}_{2}$ & 0.07 & 0.01 & 0.01 & 0.09 & 0.09 & 0.15 & 0.12 & 0.27 & 0.07 & 0.09 & 0.21 & 0.49 \\
\hline Total & 100.83 & 100.15 & 100.88 & 100.73 & 99.62 & 100.74 & 101.61 & 100.73 & 100.44 & 100.99 & 100.16 & 100.67 \\
\hline $\mathrm{Rb}^{\mathrm{b}}$ & - & - & 9 & - & 5 & - & 10 & 1 & 8 & 1 & - & - \\
\hline $\mathrm{Sr}$ & - & - & 122 & - & 127 & - & 121 & 127 & 112 & 135 & - & - \\
\hline Y & - & - & 25 & - & 25 & - & 27 & 29 & 42 & 48 & - & - \\
\hline $\mathrm{Z}_{\mathrm{r}}$ & - & - & 96 & - & 90 & - & 95 & 93 & 132 & 141 & - & - \\
\hline $\mathrm{Nb}$ & - & - & 4 & - & 4 & - & 4 & 4 & 6 & 7 & - & - \\
\hline
\end{tabular}

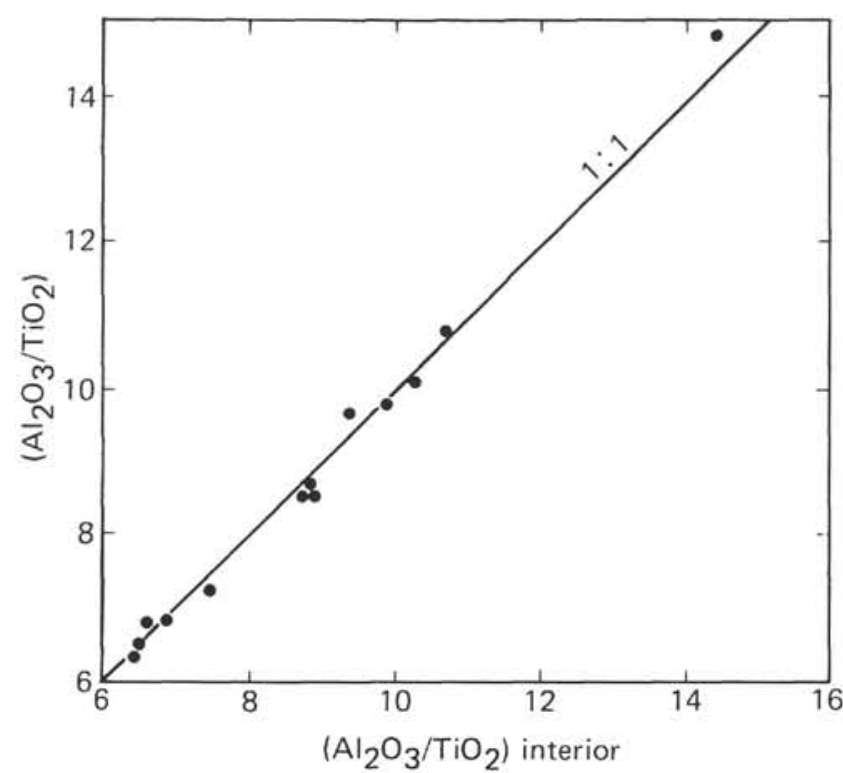

Figure 3. $\mathrm{Al}_{2} \mathrm{O}_{3} / \mathrm{TiO}_{2}$ ratios for the weathered rims and fresh interiors of basalts from the East Pacific Rise and the Galapagos Spreading Center. The solid line represents equal ratios in the rim and interior.

basalt adjacent to those fractures. This would indicate that hydrothermal alteration affects only a very small percentage of the oceanic crust, while low-temperature reactions affect a much larger volume of basalt.

The second explanation is that most of the hydrothermal minerals are formed at greater depths in the basalt column, and so were not recovered during drilling.

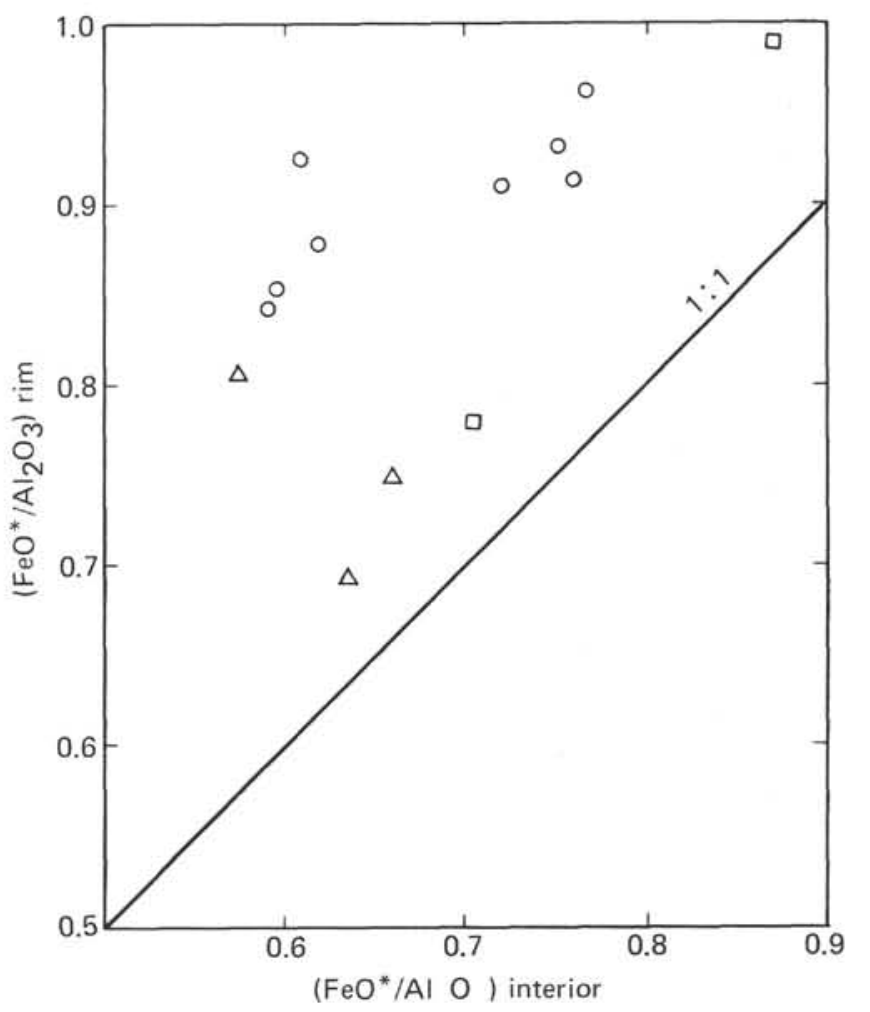

$\bigcirc=$ East Pacific Rise basalts
$\triangle=$ OCP Ridge basalts
$\square=$ Galapagos Spreading Center basalts

Figure 4. $\mathrm{FeO} * / \mathrm{Al}_{2} \mathrm{O}_{3}$ ratios in altered rims and fresh interiors, where $\mathrm{FeO}^{*}$ expresses total $\mathrm{Fe}$. 
TABLE 4 - Continued

\begin{tabular}{|c|c|c|c|c|c|c|c|c|c|c|c|c|c|}
\hline \multicolumn{2}{|c|}{$421-4-1$, Piece 5} & \multicolumn{2}{|c|}{ 420-14-1, Piece 3} & \multicolumn{2}{|c|}{ 429A-2-1, Piece 8} & \multicolumn{2}{|c|}{$429 \mathrm{~A}-2-1$, Piece 10} & \multicolumn{2}{|c|}{$429 A-2-1$, Piece 16} & \multicolumn{2}{|c|}{ 425-7-1, Piece 6} & \multicolumn{2}{|c|}{ 425-9-3, Piece 5} \\
\hline $\begin{array}{c}\text { Outer } \\
\text { Rim }\end{array}$ & Core & $\begin{array}{c}\text { Outer } \\
\text { Rim }\end{array}$ & Core & $\begin{array}{c}\text { Outer } \\
\text { Rim }\end{array}$ & Core & $\begin{array}{r}\text { Outer } \\
\text { Rim }\end{array}$ & Core & $\begin{array}{r}\text { Outer } \\
\text { Rim }\end{array}$ & Core & $\begin{array}{c}\text { Outer } \\
\text { Rim }\end{array}$ & Core & $\begin{array}{c}\text { Outer } \\
\text { Rim }\end{array}$ & Core \\
\hline 50.54 & 50.93 & 50.84 & 52.14 & 50.30 & 52.16 & 50.59 & 52.32 & 50.51 & 51.65 & 51.57 & 51.82 & 50.85 & 51.53 \\
\hline 13.68 & 14.42 & 14.20 & 15.07 & 14.21 & 15.03 & 14.19 & 15.05 & 14.19 & 15.02 & 13.63 & 14.18 & 14.61 & 14.73 \\
\hline 5.37 & 2.36 & 7.18 & 2.29 & 5.01 & 1.65 & 5.14 & 2.17 & 5.72 & 2.53 & 4.89 & 2.69 & 3.77 & 1.67 \\
\hline 7.05 & 7.85 & 5.38 & 6.20 & 6.28 & 6.48 & 6.28 & 6.13 & 6.10 & 6.10 & 7.72 & 8.73 & 6.86 & 7.81 \\
\hline 6.22 & 6.12 & 5.83 & 6.40 & 6.85 & 7.00 & 6.87 & 7.00 & 6.86 & 7.05 & 6.95 & 7.39 & 7.85 & 8.16 \\
\hline 10.64 & 10.83 & 10.78 & 11.56 & 11.36 & 11.64 & 11.20 & 11.95 & 11.08 & 11.86 & 10.81 & 11.50 & 12.01 & 12.51 \\
\hline 2.87 & 3.05 & 2.85 & 3.00 & 2.80 & 3.09 & 2.87 & 3.16 & 2.92 & 3.01 & 2.45 & 2.39 & 2.18 & 2.26 \\
\hline 0.48 & 0.36 & 0.67 & 0.31 & 0.50 & 0.23 & 0.51 & 0.31 & 0.50 & 0.27 & 0.43 & 0.05 & 0.34 & 0.07 \\
\hline 2.18 & 2.27 & 1.96 & 2.04 & 1.65 & 1.71 & 1.64 & 1.70 & 1.66 & 1.70 & 1.39 & 1.43 & 0.98 & 1.02 \\
\hline 0.20 & 0.20 & 0.19 & 0.17 & 0.15 & 0.19 & 0.16 & 0.17 & 0.21 & 0.18 & 0.18 & 0.13 & 0.11 & 0.10 \\
\hline 0.21 & 0.16 & 0.17 & 0.20 & 0.18 & 0.19 & 0.19 & 0.19 & 0.18 & 0.1 & 0.19 & 0.20 & 0.17 & 0.19 \\
\hline 0.67 & 0.51 & 1.45 & 0.47 & 0.69 & 0.77 & 0.89 & 0.69 & 1.27 & 0.60 & 0.60 & 0.34 & 0.80 & 0.53 \\
\hline 0.11 & 0.09 & 0.06 & 0.08 & 0.07 & 0.05 & 0.11 & 0.04 & 0.05 & 0.04 & 0.01 & 0.13 & 0.06 & 0.12 \\
\hline 100.22 & 99.15 & 101.56 & 99.93 & 100.05 & 100.79 & 100.64 & 100.88 & 101.25 & 100.20 & 100.82 & 100.98 & 100.59 & 100.70 \\
\hline 4 & 0 & - & 0 & 9 & - & - & - & - & - & 8 & 1 & - & 2 \\
\hline 108 & 136 & - & 135 & 111 & - & - & - & - & - & 54 & 57 & - & 55 \\
\hline 46 & 49 & - & 42 & 30 & - & - & - & - & - & 32 & 35 & - & 24 \\
\hline 142 & 146 & - & 134 & 103 & - & - & - & - & - & 74 & 77 & - & 43 \\
\hline 6 & 4 & - & 5 & 6 & - & - & - & - & - & 4 & 1 & - & 2 \\
\hline
\end{tabular}

aOxide concentrations in wt. \%.

bConcentrations in ppm.

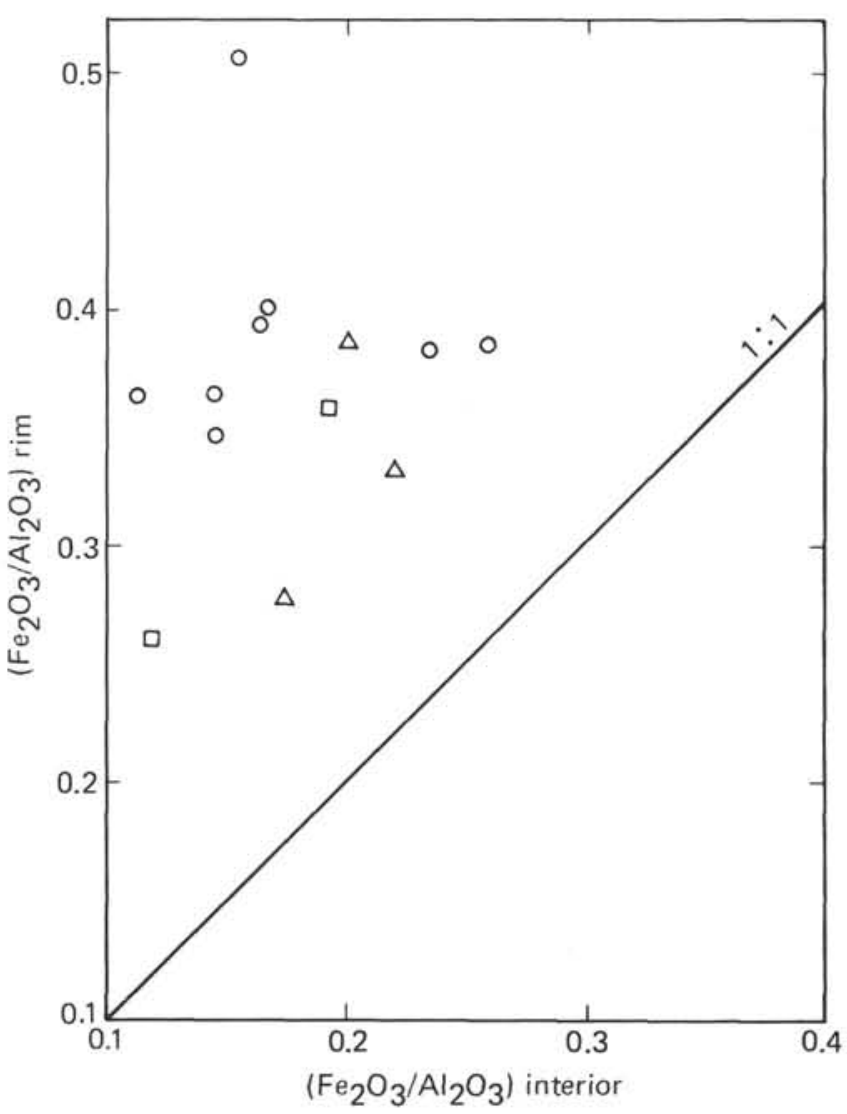

Figure 5. $\mathrm{Fe}_{2} \mathrm{O}_{3} / \mathrm{Al}_{2} \mathrm{O}_{3}$ ratios for weathered basalts of the East Pacific Rise and the Galapagos Spreading Center.

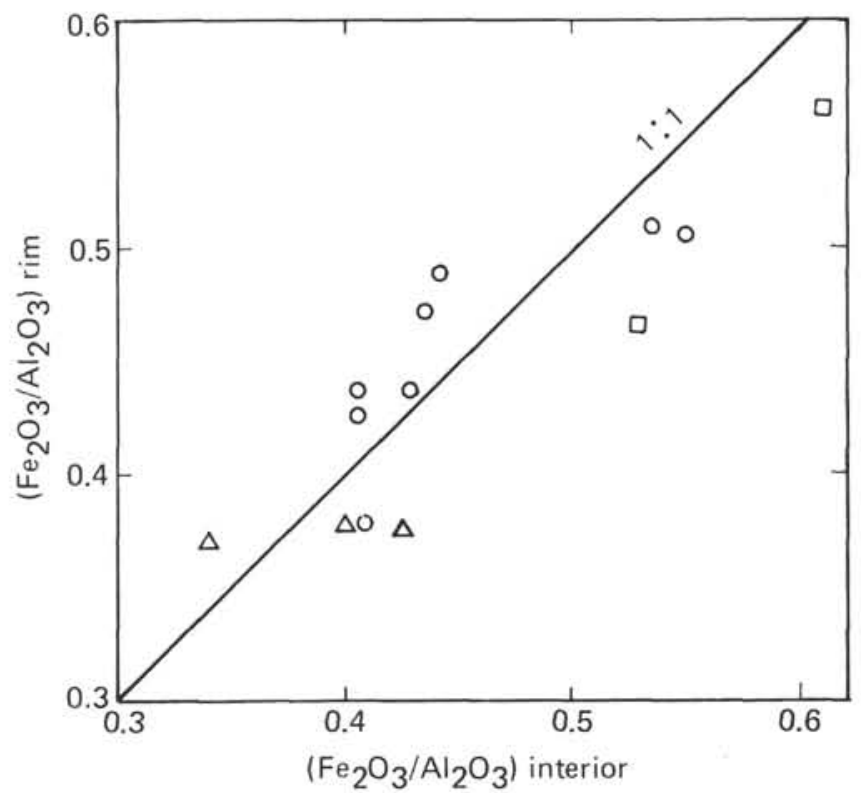

Figure 6. $\mathrm{FeO} / \mathrm{Al}_{2} \mathrm{O}_{3}$ ratios in altered rims and fresh basalt interiors.

Although hot hydrothermal fluids could percolate upward through the basalt, the highly fractured surface layers permit considerable mixing and dilution of these fluids by sea water, although some of the fluids must reach the sea floor to deposit the hydrothermal sediments. Hence, most of the evidence for hydrothermal circulation will be masked in the surface crustal layers by low-temperature rock-water interactions. 


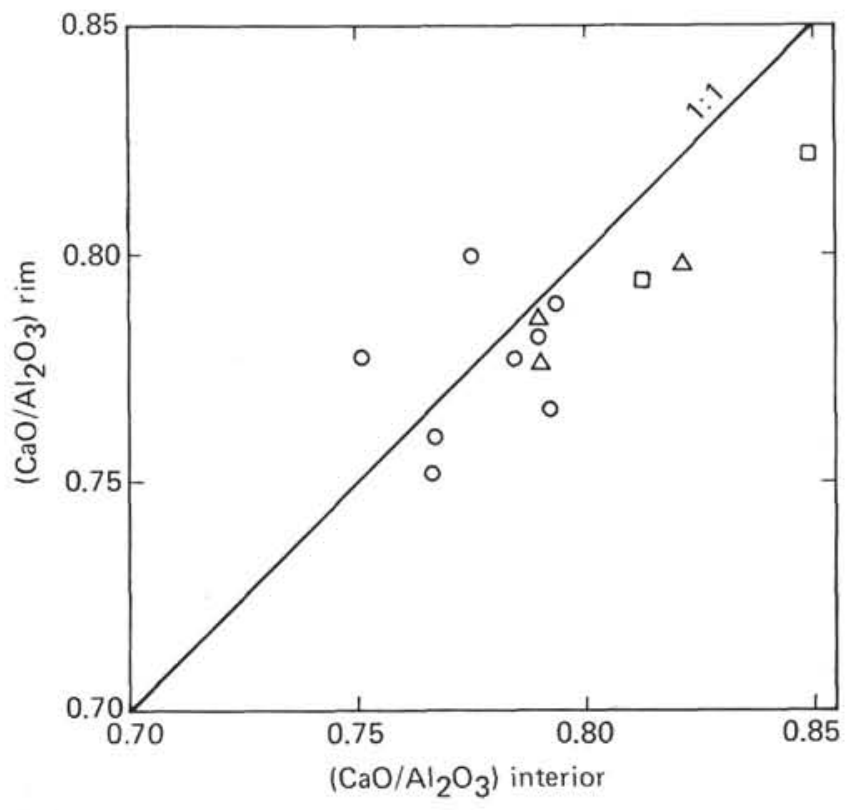

Figure 7. $\mathrm{CaO} / \mathrm{Al}_{2} \mathrm{O}_{3}$ ratios in basalts displaying weathered rims.

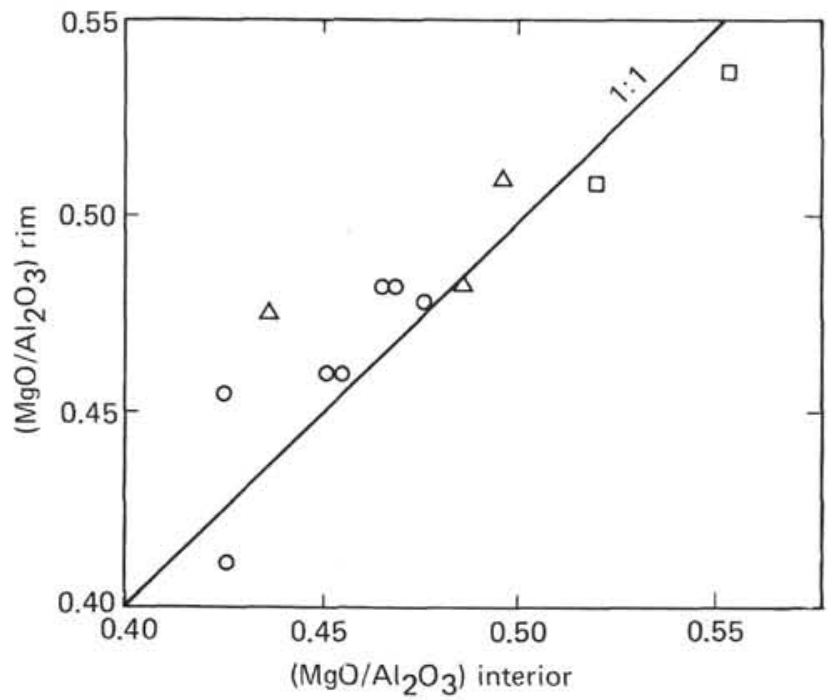

Figure 8. $\mathrm{MgO} / \mathrm{Al}_{2} \mathrm{O}_{3}$ ratios in basalts from the East Pacific Rise and the Galapagos Spreading Center.

One of the most remarkable features of the alteration mineralogy and associated chemical variations is the similarity between all the sites, even though they represent different thermal and tectonic settings. This suggests there is an initial set of reactions that ocean floor basalts undergo after eruption, regardless of the prevailing environmental conditions. If this is the case, the $\mathrm{K}$-and $\mathrm{Fe}$-enriched smectites represent the initial response of the cooling basalt to reaction with sea water. These early alteration processes must therefore occur very shortly after the emplacement of the basalts on the sea floor.

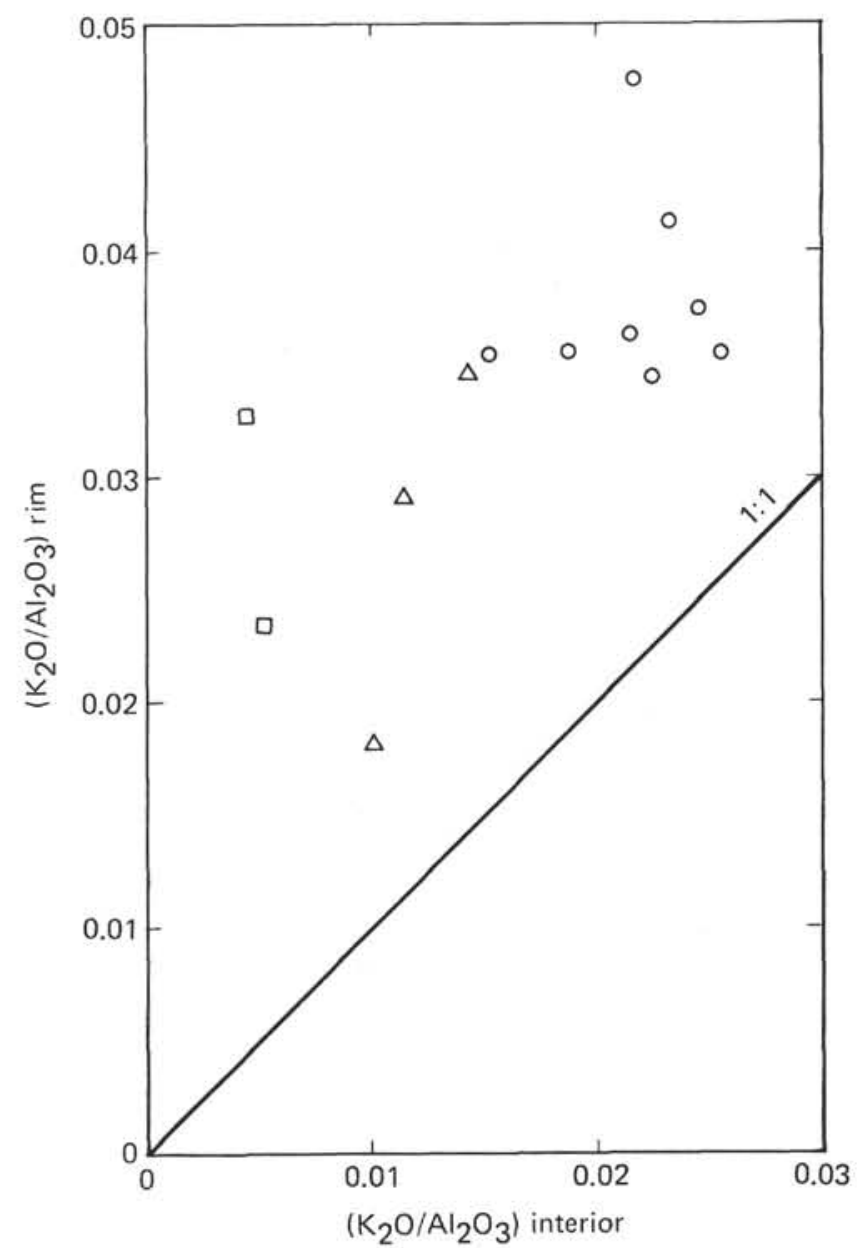

Figure 9. $\mathrm{K}_{2} \mathrm{O} / \mathrm{Al}_{2} \mathrm{O}_{3}$ ratios in basalts, showing uptake of $\mathrm{K}_{2} \mathrm{O}$ during the early stages of weathering.

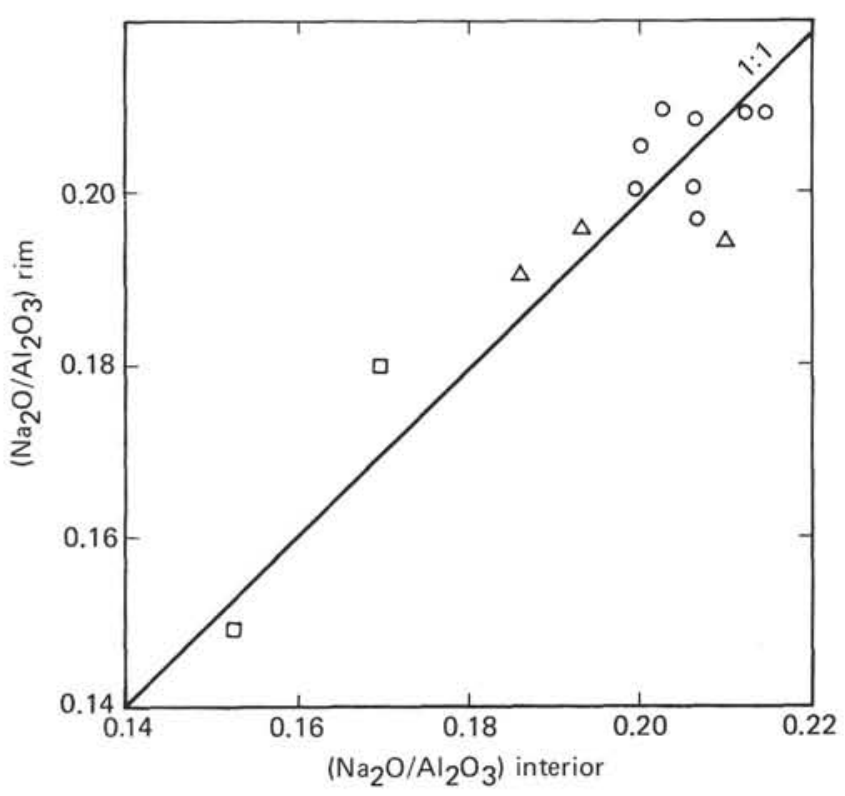

Figure 10. $\mathrm{Na}_{2} \mathrm{O} / \mathrm{Al}_{2} \mathrm{O}_{3}$ ratios in weathered basalts from the East Pacific Rise and the Galapagos Spreading Center. 


\section{ACKNOWLEDGMENTS}

We wish to thank I. L. Gibson for permission to use the XRF equipment at Bedford College, and G. F. Marriner for assistance. The British Museum (Natural History) provided the $\mathrm{CHN}$ analyzer for $\mathrm{H}_{2} \mathrm{O}^{+}$and $\mathrm{CO}_{2}$ determinations. Thanks are also due to R. Curtis, P. Grant, and D. Bailey for assistance in the laboratory at Imperial College, and to Eugene Jarosewich and Charles Obermeyer for help in running the electron microprobe at the Smithsonian Institution. 2946.

This research was supported by NERC Grant No. GR3/

\section{REFERENCES}

Donnelly, T., Thompson, G., and Salisbury, M. H., in press. The chemistry of altered basalts at Site 417, Deep Sea Drilling Project Leg 51. In Donnelly, T., Francheteau, J., Bryan, W., Robinson, P., Flower, M., Salisbury, M., et al., Initial Reports of the Deep Sea Drilling Project, v. 51, 52, 53, Part 2: Washington (U.S. Government Printing Office).

Hart, R., 1970. Chemical exchange between seawater and deep ocean basalts. Earth Planet. Sci. Letts., v. 9, p. 269.

Humphris, S. E. and Thompson, G., 1978. Hydrothermal alteration of oceanic basalts by seawater. Geochim. Cosmochim. Act, v. 42, p. 1017.
Humphris, S. E., Thompson, R. N., and Marriner, G. F., in press. The mineralogy and geochemistry of basalt weathering, Holes 417A and 418A. In Donnelly, T., Francheteau, J., Bryan, W., Robinson, P., Flower, M., Salisbury, M., et al., Initial Reports of the Deep Sea Drilling Project, v. 51, 52, 53, Part 2: Washington (U.S. Government Printing Office).

Klitgord, K. D. and Mudie, J. D., 1974. The Galapagos Spreading Centre: a near bottom geophysical survey. Geophys. J. Roy. Astr. Soc., v. 38, p. 563.

Lonsdale, P., 1977. Deep-tow observations at the mounds abyssal hydrothermal field, Galapagos Rift. Earth Planet. Sci. Letts., v. 36, p. 92.

Melson, W. G. and Thompson, G., 1973. Glassy abyssal basalts, Atlantic sea floor near St. Paul's rocks: petrography and composition of secondary clay minerals. Bull. Geol. Soc. Amer., v. 84, p. 703.

Scheidegger, K. F. and Stakes, D. S., 1977. Mineralogy, chemistry and crystallisation sequence of clay minerals in altered tholeiitic basalts from the Peru Trench. Earth Planet. Sci. Letts., v. 36, p. 413.

Thompson, G., 1973. A geochemical study of the low temperature interaction of seawater and oceanic igneous rock. Trans. Am. Geophys. Un., v. 54, p. 1015. 
PLATE 1

Section 427-9-2, Piece 9A

Figure 1 Pale blue clay mineral composed of a complex network of branching structures lining a vug.

Magnification: $\times 300$

Figure 2 Detail of the branching structures illustrating the radiating and interwoven nature of the clay mineral plates.

Magnification: $\times 1500$ 
PLATE 1

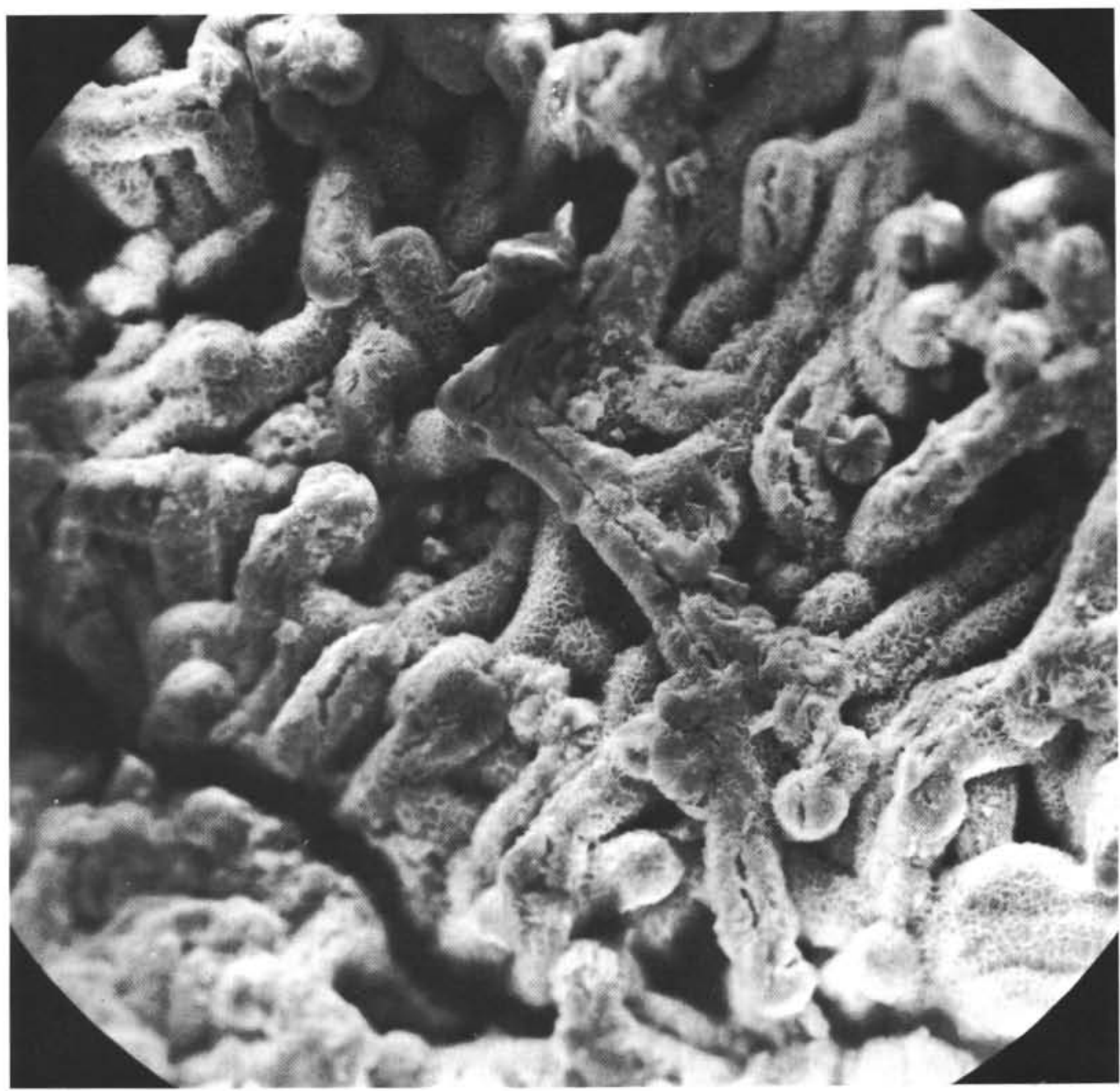

1

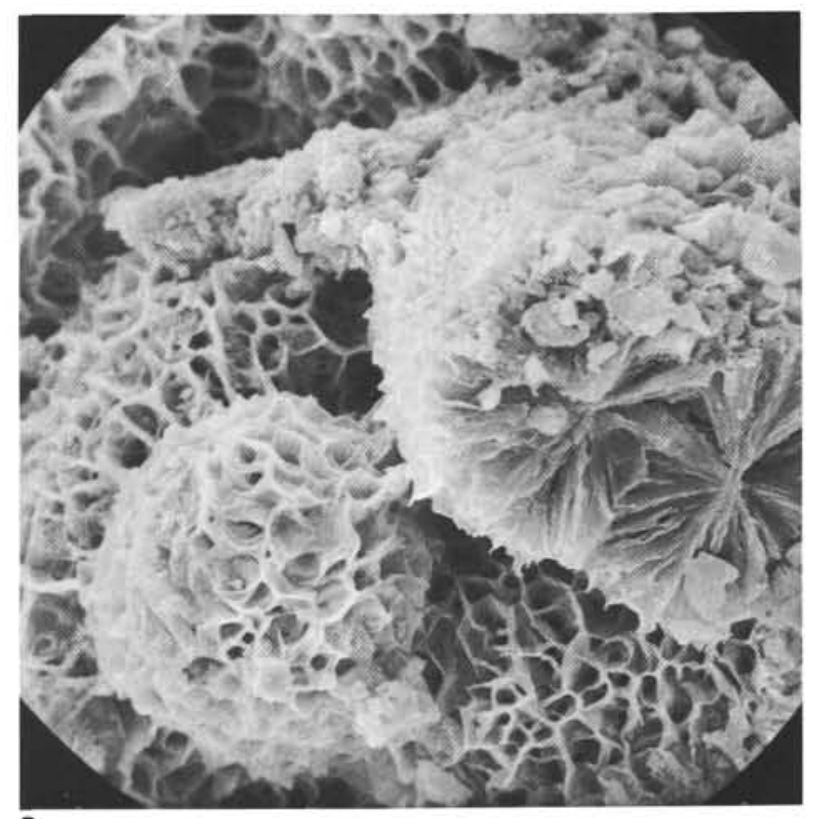

2 
PLATE 2

Section 427-9-2, Piece 12

Figure 1 Cream, globular deposit of manganese-rich calcite on rock surface.

Figure 2 Detail of surface deposit exhibiting parallel columns of stacked platelets.

Magnification: $\times 860$

Figure 3 Finer detail of manganese-rich calcite.

Magnification: $\times 2400$ 
PLATE 2

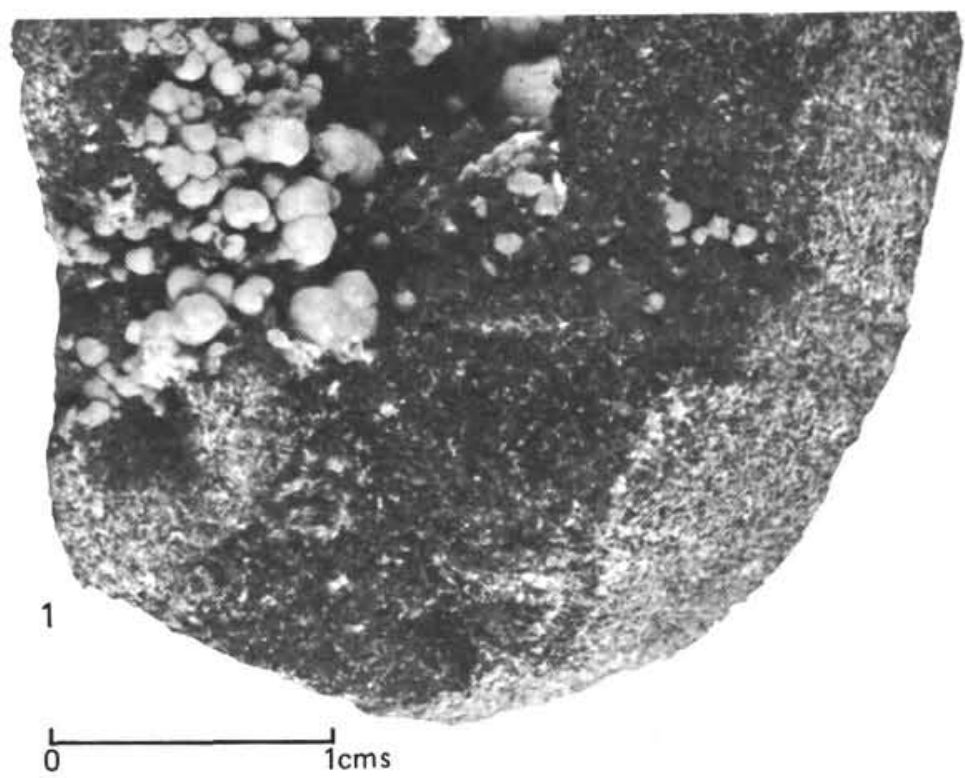

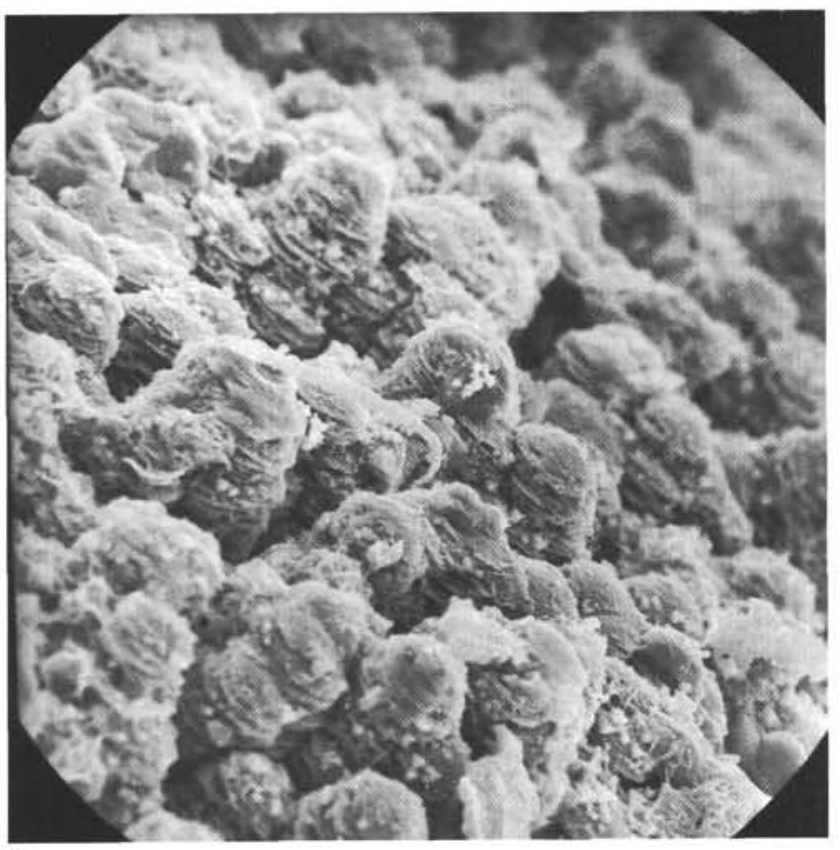

2

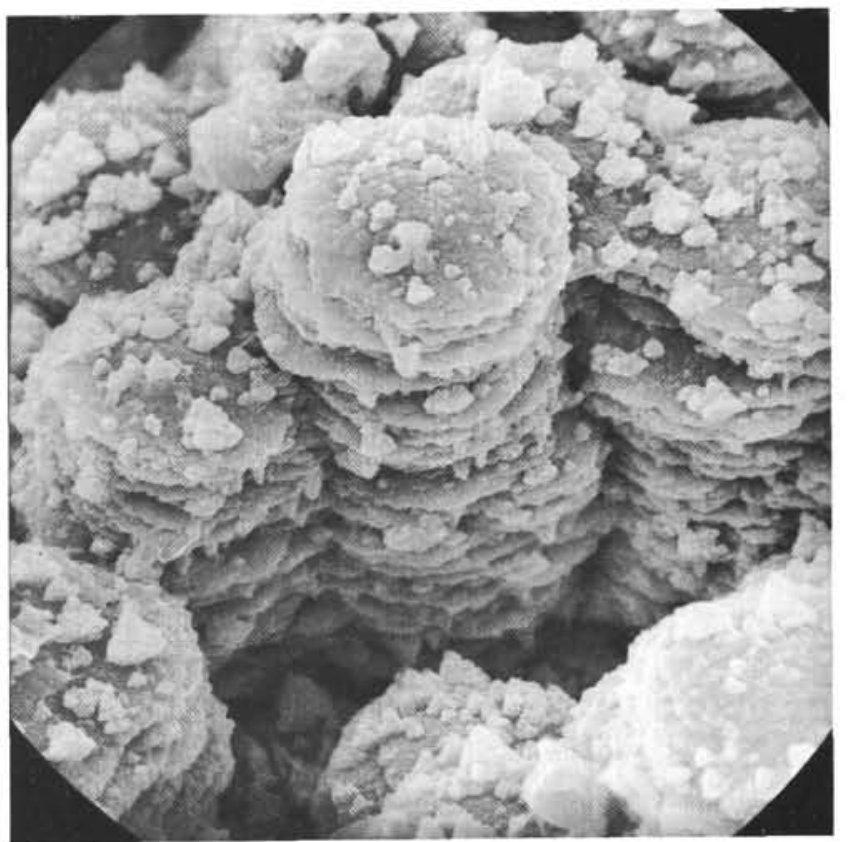

3 